\title{
Особенности морфологии и распространение Absidia spinosa в лесах Заилийского Алатау (Казахстан)
}

\section{Features of the morphology and distribution of Absidia spinosa in the forests of the Trans-Ili Alatau (Kazakhstan)}

\author{
Рахимова Е. В., Кызметова Л. А., Асылбек А. М., Ермекова Б. Д. \\ Rakhimova Y. V., Kyzmetova L. A., Assylbek A. M., Yermekova B. D. \\ Институт ботаники и фитоинтродукиии, г. Алматы, Казахстан.E-mail: evrakhim@таil.ru \\ Institute of Botany and Phytointroduction, Almaty, Kazakhstan
}

\begin{abstract}
Peфepam. В лесах Заилийского Алатау Absidia spinosa была выделена из ризосферы яблони, абрикоса, боярышника, сосны, тополя, рябины, ели и ивы. В смешанных и мелколиственных лесах на высоте 1400-2000 м над yр. м. этот вид является типичным в ризосфере абрикоса, тогда как в ризосфере ели Absidia spinosa, как типичный вид, характерна для смешанных и мелколиственных лесов с абсолютной высотой 1700-2000 м над ур. м. и хвойных лесов на высоте 1600-1900 м над ур. м. На высотах 2000-2500 м гриб встречается достаточно редко, в ризосфере ели и ивы.
\end{abstract}

Ключевые слова. Absidia spinosa, Заилийский Алатау, изолят, местонахождение, ризосфера, частота встречаемости.

Summary. In the forests of Trans-Ili Alatau, Absidia spinosa was isolated from the rhizosphere of apple, apricot, hawthorn, pine, poplar, mountain ash, spruce and willow. In mixed and small-leaved forests at an altitude of 1400-2000 $\mathrm{m}$ above sea level, this species is typical in the apricot rhizosphere, whereas in the rhizosphere of the spruce tree Absidia spinosa, as a typical species, is characteristic of mixed and small-leaved forests with an absolute height of 1700-2000 m a.s.l. and coniferous forests at an altitude of 1600-1900 m a.s.l. At altitudes of 2000-2500 $\mathrm{m}$, the fungus is quite rare in the rhizosphere of spruce and willow.

Key words. Absidia spinosa, frequency of occurrence, isolate, location, rhizosphere, Trans-Ili Alatau.

\section{Введение}

Заилийский Алатау протяженностью почти 380 км, шириной 30-40 км и высотами, достигающими почти 5000 м над ур. м., является самым северным хребтом Тянь-Шаня. Северный макросклон Заилийского Алатау состоит из более мелких боковых хребтов (Талгар, Кумбель и др.), сильно рассеченных многочисленными ущельями. Наиболее крупные реки - Узын-Каргалы, Чемолган, Аксай, Каскелен, Большая и Малая Алматинки, Иссык, Тургень - стекают по северному макросклону. Южный макросклон Заилийского Алатау очень крутой и короткий, рассеченный короткими и узкими долнами рек, впадающими на западе в р. Кемин, на востоке - в р. Чилик. Климат Заилийского Алатау меняется в зависимости от высотно-климатических зон. Средняя температура января в предгорье $-7,4{ }^{\circ} \mathrm{C}$, в высокогорье $-11,3{ }^{\circ} \mathrm{C}$. Средняя температура июля $+23{ }^{\circ} \mathrm{C}$ и $+7{ }^{\circ} \mathrm{C}$, соответственно. Осадки увеличиваются от 560 мм в предгорье до 800-1300 мм в высокогорье. Количество дней с устойчивым снеговым покровом от 111 до 236 на разных высотах. Растительность Заилийского Алатау характеризуется специфичным спектром высотных поясов. Здесь отсутствуют непрерывный пояс еловых лесов и пояс альпийских тундр. Отличительным признаком является широкое распространение всех подтипов горных степей (Ботаническая география ..., 2003).

Несмотря на то, что разнообразие экологических условий хребта, а также своеобразный состав растений-хозяев не могли не повлиять на количество и соотношение различных групп грибов (Шварцман, 1962), в микологическом отношении Заилийский Алатау исследован недостаточно, особенно сла- 
бо изучена биота почвенных грибов. Целью предлагаемой статьи является описание морфологии и распространение Absidia spinosa Lendn. (Zygomycota Moreau, Mucoromycotina Benny, Mucorales Dumort., Mucoraceae Dumort.) в лесах Заилийского Алатау (Казахстан).

\section{Материалы и методы}

Образцы почвы были собраны в вегетационный период 2018 г. (апрель, июль и август). Местами отбора проб были ризосфера деревьев темнохвойных, мелколиственных и смешанных лесов на горнолесных почвах в Заилийском Алатау. Темнохвойные леса состоят из основной лесообразующей породы ели шренской (Picea schrenkiana Fisch. et C. А. Меу.). Подлесок состоит из рябины, осины, различных видов шиповника, жимолости, можжевельника, ивы. Нижнюю зону Заилийского Алатау и долины рек занимают смешанные лиственно-еловые леса. Содоминирующими видами здесь являются яблоня, абрикос, ива, береза, осина. Образцы отбирались в почвенном горизонте 5-20 см после удаления верхнего слоя подстилки в ризосфере различных древесных растений. Географическое положение каждого места сбора образцов было записано с использованием GPS (Germin). Почвенные грибы выделяли методом серийных разведений (Поликсенова и др., 2004). В качестве питательной среды использовали картофельно-сахарозный агар, культивирование грибов велось при $25^{\circ} \mathrm{C}$. Цвет, внешний вид, текстуру и скорость роста колоний наблюдали и фотографировали в возрасте 5-10 дней. Для световой микроскопии мелкие кусочки растущей грибной колонии исследовали и фотографировали с использованием фотомикроскопа Polyvar с интерференционной контрастной оптикой Номарского. Были проведены измерения различных грибных структур. Образцы были идентифицированы с помощью литературы по почвенным зигомицетам (Пидопличко, Милько, 1971; Watanabe, 2002). Частота встречаемости вида была установлена по формуле: А = В / C × 100 \%, где А - частота встречаемости вида; В - количество образцов, в которых вид был обнаружен; С - общее количество исследованных образцов (Мирчинк, 1988).

\section{Результаты и обсуждение}

Всего было отобрано 44 образца почвы в трех повторностях, из 11 образцов была выделена Absidia spinosa.

Местонахождения вида: Заилийский Алатау, Иле-Алатауский государственный национальный природный парк (ИАГНПП), Большое Алматинское ущ., «смешанный лес, в ризосфере сосны, т. 315в, 1703 м над ур. м., N4306' $18.3^{\prime \prime}$, E7654'49.6". 30 VIII 2018. Е. В. Рахимова»; там же, «склон северо-западной экспозиции, смешанный лес, в ризосфере ивы, т. 299a, 2312 м над ур. м., N430. $4^{\prime} 19.8^{\prime \prime}$, E76 59'11.1". 06 VIII 2018. У. К. Джетигенова»; там же, «смешанный лес, в ризосфере абрикоса, т. 262, 1926 м над ур. м., N4306'27.1", E7656'15.9", 27 IV 2018; Е. В. Рахимова»; там же, «в ризосфере тополя, смешанный лес, т. 258, 1930 м над ур. м., N4306'28.7", E7656'21.2", 27 IV 2018, Л. А. Кызметова»; там же, «склон северной экспозиции, еловый лес, в ризосфере ели, т. 301, 2377 м над ур. м., N4304'08.5", E7659'27.2", 09 VIII 2018, А. М. Асылбек»; там же, «т. 256, 1924 м над ур. моря,

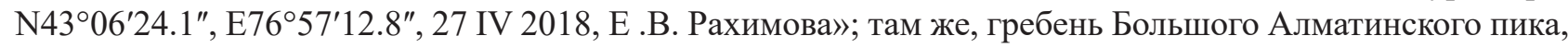
«смешанный лес, в ризосфере боярышника, т. 309a, 1477 м над ур. моря, N4306'37.0", E76 54'53.1", 29 VIII 2018, А. М. Асылбек»; там же, «смешанный лес, в ризосфере абрикоса, т. 310б, 1504 м над ур. м., N4306'36.2", E7654'49.1", 29 VIII 2018, А. М. Асылбек»; там же, «еловый лес, в ризосфере яблони, т. 313, 1628 м над ур. м., N4306'26.0", E7654'46.6", 29 VIII 2018, Е. В. Рахимова»; там же, ущ. Аюсай, «склон юго-восточной экспозиции, еловый лес, в ризосфере ели, т. 304, 1831 м над ур. м., N430 $05^{\prime} 43.4^{\prime \prime}$, E76 56'44.9", 27 VIII 2018, Л. А. Кызметова»; там же, «опушка сосняка, в ризосфере сосны, т. 314, 1667 м над ур. м., N4306'21.9", E7654'47.9", 30 VIII 2018, Е. В. Рахимова».

Absidia spinosa была выделена из ризосферы яблони, абрикоса, боярышника, сосны, тополя, рябины, ели и ивы. Чаще всего вид отмечен в ризосфере ели, сосны и абрикоса. Колонии быстрорастущие, пушистые, до 1 см высотой, бежевые, сероватые. Мицелий большей частью неклеточный. Септы появляются с возрастом при дифференциации мицелия на столоны, ризоиды и субстратный мицелий. Ризоиды хорошо развитые, разветвленные. Хламидоспоры встречаются крайне редко, обычно в субстратном мицелии, развиваясь терминально или интеркалярно. Прямые, с поперечной перегородкой в верхней части, неокрашенные или слегка коричневатые спорангиеносцы расположены в мутовках на 
столонах (рис. 1,2). Диаметр спорангиеносцев колеблется от 7,0 до 10,5 мкм, а диаметр спорангиевот 24,0 до 40,0 мкм (табл. 1, рис. 3). Разрушение спорангия происходит после созревания шаровидных спорангиоспор. Колумелла полусферическая, иногда приплюснутая, с тонким придатком (до 8 мкм) на вершине (рис. 4). Гаметангии обычно имеют одинаковый размер (рис. 5). Иногда наблюдается гетероталлизм, при котором на гифах разных мицелиев развиваются гаметангии неодинаковой величины. При этом более мелкий гаметангий обычно лишен придатков. Зигоспора, развивающаяся после слияния гаметангиев, имеет простые серповидные изогнутые или в виде неполного спирального завитка, шероховатые придатки (рис. 6). С возрастом и зигоспора и придатки становятся более темно окрашенными. Формирование зигоспор отмечено только в изолятах, полученных из ризосферы ели.

Таблица 1

Размеры разных структур изолятов Absidia spinosa, мкм

(прочерк в столбце означает отсутствие измерений)

\begin{tabular}{|c|c|c|c|c|}
\hline \multirow{2}{*}{$\begin{array}{c}\text { Номер точки/ } \\
\text { образца }\end{array}$} & \multicolumn{4}{|c|}{ Диаметр } \\
\cline { 2 - 5 } & спорангиеносца & спорангия & колонки & зигоспоры \\
\hline 256 & $7,0-10,5$ & $24,0-31,5$ & $7,0-24,0$ & - \\
\hline 301 & 7,5 & 30,8 & $21,5-26,0$ & 90,0 \\
\hline 304 & - & - & - & $50,0-80,0$ \\
\hline 309 a & - & - & $20,0-21,5$ & - \\
\hline 313 & $7,0-8,5$ & 32,0 & - & - \\
\hline 314 & $8,5-9,5$ & $36,5-40,0$ & - & - \\
\hline 315 в & $7,5-8,5$ & $32,0-35,0$ & - & - \\
\hline
\end{tabular}

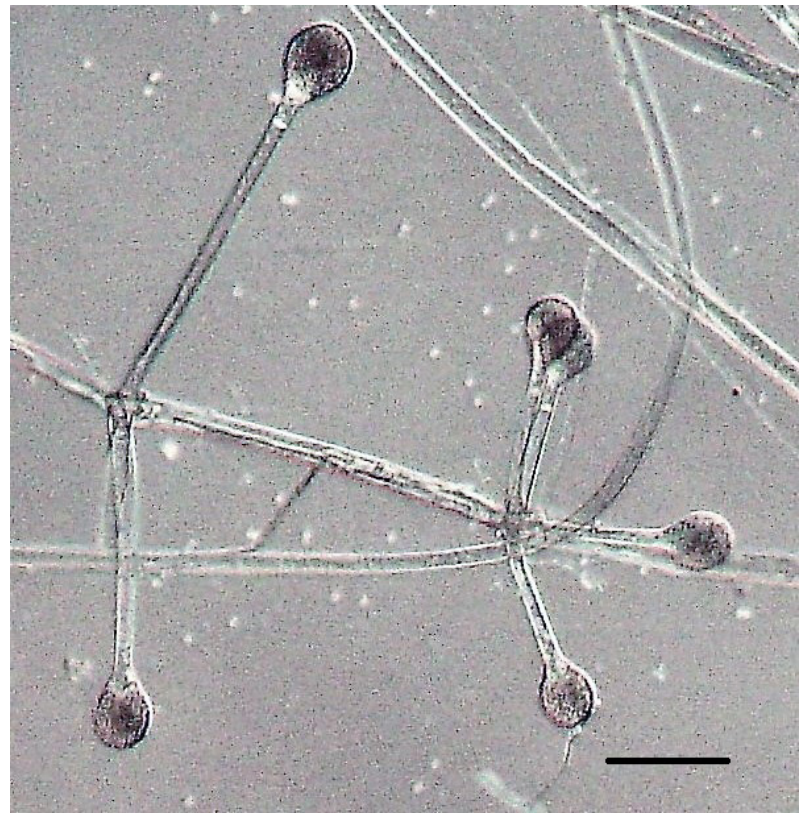

Рис. 1. Спорангиеносцы Absidia spinosa на столоне. Шкала $=70 \mu \mathrm{m}$.



Рис. 2. Мутовка спорангиеносцев Absidia spinosa. - Шкала $=35 \mu \mathrm{m}$.

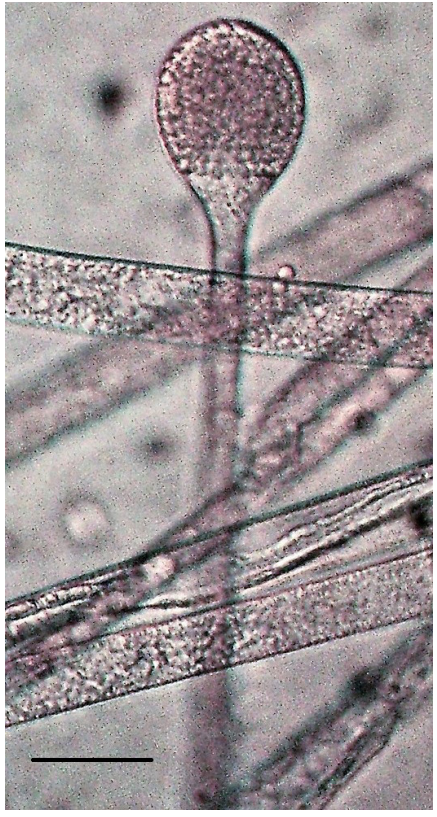

Рис. 3. Спорангий Absidia spinosa, внутри видны споры. - Шкала $=30 \mu \mathrm{m}$

Следует отметить, что в лесах Заилийского Алатау вид Absidia spinosa наблюдается в широком диапазоне высот (табл. 2). В смешанных и мелколиственных лесах на высоте 1400-2000 м над ур. м. этот вид является типичным в ризосфере абрикоса, тогда как в ризосфере ели Absidia spinosa, как типичный вид, характерна для смешанных и мелколиственных лесов с абсолютной высотой 1700-2000 м над ур. м. и хвойных лесов на высоте 1600-1900 м над ур. м. На высотах 2000-2500 м над ур. м. гриб встречается достаточно редко в ризосфере ели и ивы. 




Рис. 4. Колонки Absidia spinosa с придатками на вершине. - Шкала $=30$ $\mu \mathrm{m}$.

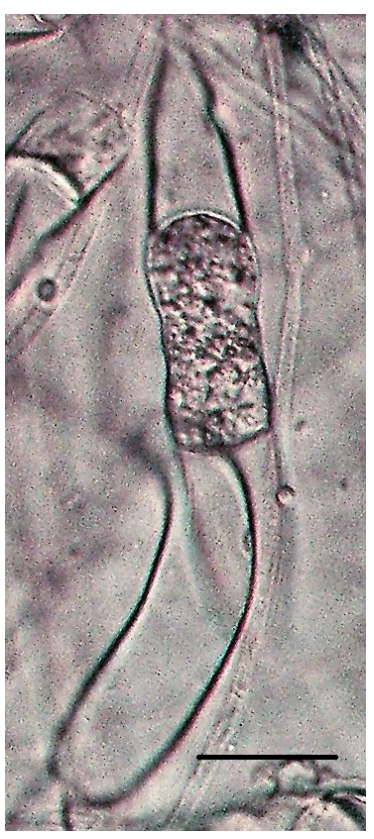

Рис. 5. Коньюгация гаметангиев Absidia spinosa. - Шкала $=15 \mu \mathrm{m}$.



Рис. 6. Молодая зигоспора Absidia spinosa с серповидными придатками. - Шкала $=50 \mu \mathrm{m}$.

Таблица 2

Частота встречаемости (\%) Absidia spinosa в различных местообитаниях (- - вид отсутствует, + - случайный вид, частота встречаемости $-\mathrm{A}<30 \%$, ++- типичный вид, $\mathrm{A}>30 \%,+++$ - доминирующий вид, $\mathrm{A}>50 \%$ )

\begin{tabular}{|l|c|c|c|c|c|c|}
\hline \multirow{2}{*}{$\begin{array}{c}\text { Ризосфера } \\
\text { видов }\end{array}$} & \multicolumn{2}{|c|}{ Смешанные и мелколиственные леса } & \multicolumn{3}{c|}{ Хвойные леса } \\
\cline { 2 - 7 } & $\begin{array}{c}1400-1700 \\
\text { м н.у.м. }\end{array}$ & $\begin{array}{c}1700-2000 \\
\text { м н.у.м. }\end{array}$ & $\begin{array}{c}2000-2300 \\
\text { м н.у.м. }\end{array}$ & $\begin{array}{c}1600-1900 \\
\text { м н.у.м. }\end{array}$ & $\begin{array}{c}1900-2200 \\
\text { м н.у.м. }\end{array}$ & $\begin{array}{c}2200-2500 \\
\text { м н.у.м. }\end{array}$ \\
\hline абрикос & ++ & ++ & - & - & - & - \\
\hline боярышник & + & - & - & - & - & - \\
\hline ель & - & ++ & - & ++ & + & + \\
\hline ива & - & - & + & - & - & - \\
\hline сосна & - & + & - & + & - & - \\
\hline тополь & - & + & - & - & - & - \\
\hline яблоня & - & - & - & + & - & - \\
\hline
\end{tabular}

Виды рода Absidia характерны также для почв хвойных лесов российского Дальнего Востока (Егорова, 2009) и для почв горных хребтов, расположенных в Арктике за полярным кругом (Кирцидели, 2016). По мнению ряда исследователей, интенсивное развитие представителей рода Absidia связано с высоким содержанием плохо разложившихся органических веществ в почве (Дьяков, 2003; Берсенева и др., 2008), что характерно так же для грибов рода Mисоr. Этим можно объяснить высокую встречаемость Absidia spinosa в ризосфере ели в лесах Заилийского Алатау.

Благодарности. Работа выполнена при финансовой поддержке проекта «Оценка влияния почвенного запаса микромицетов на восстановительный потенциал лесов Заилийского Алатау после пожаров», ИРН АР05131258. 


\section{ЛИТЕРАТУРА}

Берсенева О. А., Саловарова В. П., Приставка А. А. Почвенные микромицеты основных природных зон // Известия ИрГУ. - Серия Биология, экология, 2008. - Т. 1, №1. - С. 3-9.

Ботаническая география Казахстана и Средней Азии (в пределах пустынной области). / Под ред. Е. И. Рачковской, Е. А. Волковой, В. Н. Храмцова. - СПб., 2003. - 424 с.

Дьяков Ю. Т. Грибы и растения. - Природа, 2003. - №5. - С. 73-78.

Еzорова Л. Н. Почвообитающие зигомицеты (Zygomycetes: Mucorales, Mortierellales) хвойных лесов Российского Дальнего Востока // Микология и фитопатология, 2009 - Т. 43, № 4. - С. 292-297.

Кирцидели И. Ю. Микроскопические грибы в почвах и грунтах арктических горных систем // Биосфера, 2016. - Т. 8, № 1. - С. 63-78.

Мирчинк Т. Г. Почвенная микология. - Москва: Изд-во МГУ, 1988. - 219 с.

Пидопличко Н. М., Милько А. А. Атлас мукоральных грибов. - Киев: Наукова думка, 1988. - 204 с.

Поликсенова В. Д., Храмцов А. К., Пискун С. Г. Методические указания к занятиям спецпрактикума по разделу «Микология. Методы экспериментального изучения микроскопических грибов». - Мн.: Изд-во БГУ, 2004. $-36 \mathrm{c}$.

Шварцман С. $\boldsymbol{P}$. Материалы к истории микофлоры Казахстана (Дополнение к II тому «Флоры споровых растений Казахстана. Головневые грибы») - Алма-Ата: Изд-во АН КазССР, 1962. - 182 с.

Watanabe T. Pictorial atlas of soil and seed fungi: Morphologies of cultured fungi and key to species. - CRC Press, 2002. $-486 \mathrm{p}$. 